\title{
THERAPEUTIC LANDSCAPES: AN INTEGRATIVE APPROACH IN THE DESIGN OF URBAN GREEN SPACES
}

\author{
Assoc. Prof. Dr. Parisa GÖKER ${ }^{\star}{ }_{1}$, Asist. Prof. Dr. Hilal KAHVECi \\ *Bilecik Şeyh Edebali University, Fine Arts and Design Faculty, Department of Interior Architecture and \\ Environmental Design, Bilecik
}

\begin{abstract}
Numerous theories have been used to present Biophilia Hypothesis in order to clarify the great interest and gratification about natural environments. The concept of Biophilia points out that there must be a biological connection with nature at the physical, spirutal and social levels. Hence, our personal well-being, productivity and social relations are positively influenced when our urban environment incorporates natural components. It has been well known ever since the middle-ages that healing gardens affect psychological and physical health of humans. The concept of therapeutic gardens has been generated in the scope of the healing functions of green areas in the face of negative effects of rapid urbanization by considering the recent effects of green areas on human life. In this study, building of therapeutic gardens in the historical process and their effects on human life were scrutinized. Moreover, general urban green area uses were investigated and they were assessed in the scope of therapeutic garden improvement. Improvement types of therapeutic gardens, design criteria, place arrangement and plant material use were studied. Consequently, it is a scientifically accepted reality to consider the decisions "an integrated approach" in planning studies for determining the therapeutic and curative (physical, spiritual) roles of green systems for urban residents in urban areas.
\end{abstract}

Keywords: Healing garden, therapeutic garden design, landscape design.

\section{Introduction}

It is suggested by the Biophilia Hypothesis that the human kind has an attraction to several aspects of natural environment based on a biological perspective, while the welfare of the same depends on his relationship with the world of nature surrounding them (Wilson, 1984; Kellert, 1997; Kellert, 2002; Kellert, 2008). The Biophilic Design Framework has been created out of the Biophilia Hypothesis (Orman, 2017), setting forth an informative proposal that affinity of people and association with nature depend on hereditary and ecological adjustment forms. Gardens have been built for sustaining health and wellness throughout history ever since the middle-ages up until today (Erickson, 2012). There is a complex interaction between humans and nature however positive effects of nature on physical and psychological health of humans have not been defined clearly. In addition, it has been reported that nature influences spiritual well-being of humans (Kendle and Rohde, 1995). It has been reported in literature that psychology of people who live in cities and maintain interaction with nature and environment has been affected positively. This implies that synergy with nature impacts human psychology in a positive way. There is an active contact taking place between humans and nature, and a passive contact occurs when people only observe nature, for example when they look at plants in a park or when they see trees through a window. There are various ways for people to benefit from nature, and psychological benefit is attained when people become aware that they can take advantage of nature at their own will (Göker, 2017).

\section{Therapeutic / Improvement Gardens throughout the Historical Process}

Starting from Persian gardens, the oldest gardens are known to be built because of their restorative characteristics. The earliest Persian gardens were created in the $6_{\text {th }}$ Century, BC. Persian gardens were designed as to align lush green plants in a geometrical way in an organized place. These gardens displayed signs of an apparent and also a sacred, concealed delicacy: possibility of a solemn organization within a complexity, ever-lasting life despite of mortality, and tranquility following torment (Khansari, Moghtader, and Yavari 1998). Garden components were organized to build a relaxing site to alleviate stress and to promote 
thinking. Some of the examples of the thought gardens are gardens of the Far East, including Japanese Zen Gardens. Gardens and faith go hand in hand in Japan. According to the Japanese belief, natural components of a garden manifest gods and hence, it is possible to see these components in religious institutions. These gardens were erected to offer guidance and consoling to visitors. Zen gardens started to be common in the $12_{\text {th }}$ Century and they had reviving characteristics especially. Zen involves meditation and connection to the universe. These Japanese meditation gardens gained an extra aspect through this practice. In the 17 th and $18_{\text {th }}$ Centuries, outdoor sites started to be incorporated into hospital plans. Because of new advances and investigations on infectious diseases, hospital plans started to attach importance to access to fresh air, crossventilation, and hygiene. Hospitals consisted of wide spaces and high-quality soil, and attempted to benefit from sunlight and wind in order to regulate climate. A series of wards connected by a service hall were incorporated into the hospital design, resembling the teeth of a comb. These hospitals were called pavilion hospitals and small garden sites were built among the wards (Marcus and Barnes 1999).

It has been proven scientifically that spending time in green areas and gardens have positive psychological and physiological effects on humans. Green areas, nature, sunlight and fresh air have been defined as the major components of health ever since the Middle Ages up until the beginning of the 19 th Century. Effects of nature on human health were assessed by various cultures and societies and different methods were used for this purpose, including Zen and monastery gardens. But, since the beginning of the 20 th Century, technological advancements have played a major role in medicine, and traditional healing methods have been replaced by technological methods. In the 1990s, green area and natural therapy studies have come into prominence in the 1990s once again and the designers started to come up with green area-focused designs. Society of Landscape Architectures started to give seminars on healing gardens in the United States during 1998-1999. Researchers investigated the effects of human and nature relationship on health during this period and proposed the term of healing gardens. Healing gardens have significant effects on mental, physical and psychological health of humans. Moreover, they strengthen their physical, emotional and social aspects as well (Göker, Tuna 2017).

\section{Healing Gardens}

The healing term is used widely and it represents the entire beneficial methods resorted to improve felicity. Healing gardens, on the other hand, are areas designed to make people feel better psyhologically and physically. Healing gardens aim to minimize negative effects of stress. Stress has an effect leading to the development of new diseases in healthy individuals and worsening the present health situation of individuals who suffer from an illness (Ayaşıgil, 2011). Healing gardens are designed to take people away from stressful environments. Healing gardens, also called the outdoor therapy units, are designed as a place where people feel themselves better physically, psychologically and physiologically and where they can perform motivationimprovement, hiking, walking, relaxation, observation and physical activities. In general sense, these gardens ensure people find peace and healing by communicating with people by means of their five senses. There are two critical principles involved in the design of healing gardens, namely active and passive garden principles. Gardens providing direct physical interaction with the environment (planting flowers and growing plants, etc.) are defined as active gardens. In passive gardens, therapy and healing methods are provided by means of only seeing, hearing and sensations. In healing gardens, passive and active uses must be considered in the design stage in order to provide optimum use (Vappa, 2002).

\section{Healing gardens are categorized under four titles;}

According to Marcus and Barnes 1999; there are two significant principles for the healing garden design; active and passive gardens. Gardens that have a direct interaction with the environment physically (planting flowers, cultivating plants, etc.) are defined as active. In the passive method, on the other hand, therapy and healing methods only with eyesight, hearing and sensation are provided. Passive and active usages must be considered at the design stage to ensure optimum usage in healing gardens. Healing gardens are classified under four headings (Göker, Tuna, 2017);

- Meditation gardens; Meditation gardens are small, restricted, peaceful and tranquil places. Focus-point concentration is involved in their design, and they attempt to improve inner-peace and concentration and to alleviate stress of daily life in the healing process.

- Therapeutic Gardens; Therapeutic gardens are built to allow people to get away from chaotic environments. These gardens are also referred to as therapy centers and are designed to offer people 
physical, psychological and physiological relief, and an opportunity to advance their physical movements and motivations, and to offer hiking, walking, resting and observation opportunities. People are able to use their five senses when they spent time in these gardens generally and find tranquilty and healing.

- Restorative Gardens; Restorative gardens are erected for the benefit of both patients and healthy people. These gardens promote healthy people to become assertive in their social settings. They offer relief to people and prepare them for personal comtemplation or they arouse the sensation of belonging to a community when they spend time in these gardens. The principles of behavioral and social sciences were applied in the design of restorative gardens.

- Enabling gardens; Enabling gardens offer entertainment to people of any age group according to their personal abilities and limitations. These gardens are built for the elderly and disabled people particularly. In designing sites for the elderly and disabled, safety and convenience must be taken into consideration as the most critical aspects.

\section{Fundamental Features of Healing Gardens}

Ten major concepts are influential in the therapeutic and healing aspects of healing gardens. These are plainness, privacy, tranquility, inner security, emotive stimulation, legibility, socialization means, physical activity means, sense of comfort and safety. Effects of the meditation, healing, restorative and enabling gardens are discussed below under four titles in the scope of healing gardens (Sacamano 2009).

Table1: Fundamental Features and Design Framework of Healing Gardens

\begin{tabular}{|c|c|c|}
\hline & $\begin{array}{l}\text { Fundamental Features of Healing } \\
\text { Gardens }\end{array}$ & $\begin{array}{lll}\text { Healing Garden } & \text { Design } \\
\text { Framework } & & \\
\end{array}$ \\
\hline Meditation gardens & $\begin{array}{l}\text { plainness, privacy, tranquility and } \\
\text { mental health }\end{array}$ & \multirow{4}{*}{$\begin{array}{l}\text { - Sense of control and having } \\
\text { privacy } \\
\text { - Social support } \\
\text { - Physical movement and activity } \\
\text { - Access to nature and presence of } \\
\text { other positive distractions } \\
\text { - Reducing uncertainty and } \\
\text { presence of non-physical } \\
\text { materials } \\
\text { - Reducing intrusive influences }\end{array}$} \\
\hline Therapeutic gardens & $\begin{array}{l}\text { Use of the five senses and mental } \\
\text { health and legibility }\end{array}$ & \\
\hline Restorative gardens & $\begin{array}{l}\text { offering socialization means and } \\
\text { physical activity means, tranquility and } \\
\text { mental health }\end{array}$ & \\
\hline Enabling gardens & $\begin{array}{l}\text { active interaction with nature, and } \\
\text { sense of security in the location }\end{array}$ & \\
\hline
\end{tabular}

\section{Fundamental Features of Healing Gardens}

There are ten fundamental concepts involved in healing gardens in terms of healing and therapy effects. These are offering simplicity, privacy, tranquility, inner-peace, sensual stimulation, legibility, socialization and physical activity opportunities and the sense of comfort and safety.

\section{Privacy}

Healing gardens, particularly meditation and restorative gardens have some prominent characteristics, namely offering privacy and private use spaces. Restorative garden designing must incoporate direct interaction with plants by including private use spaces and walking trails.

\section{Tranquilty}

The main component of meditation, restorative and healing gardens is arousing sense of peace and tranquility. These gardens affect the five sense organs (eyesight, hearing, sensation, smell, and touching) of people by offering peace and in addition, they alleviate stress in the inner-world of people and improves life quality of patients and healthy people spending time there.

\section{Perceptibility}

The design of healing gardens must involve perceptibility and convenience in use and must incorporate walking trails and sites for activities and relaxation. The incorporated sites must be perceptible and have no objects obscuring the view by considering the perspective of the users. 


\section{Permitting social activities}

The conducted scientific researches have reported that people involved in social activities are healthier in comparison to depressive and lonely people as social activities and interaction with people have positive effects in disease treatment. Thus, there must be sitting sites for social activities and for healthy or ill persons to spend time together in healing gardens and particularly in restorative and healing gardens.

\section{Permitting physical activities}

Restorative gardens offer means for physical activity as a fundamental feature. Restorative gardens must incorporate walking spaces and sites for physical activities at the center of the garden, and it is critical that walking areas must not be very large.

\section{A sense of security}

Offering sense of security is a critical aspect of healing gardens and enabling gardens particularly because they must maintain direct interaction with nature. It is important that sense of security is provided for patients and healthy users. Their design must minimize falling, wandering, panicking and stress and must offer sense of security.

\section{Framework to Design Therapeutic Landscapes}

During the Therapeutic garden design process, there are important points to be considered within both the scope of the area selection and the use of structural and plant materials. These criteria and important items to be considered are as follows;

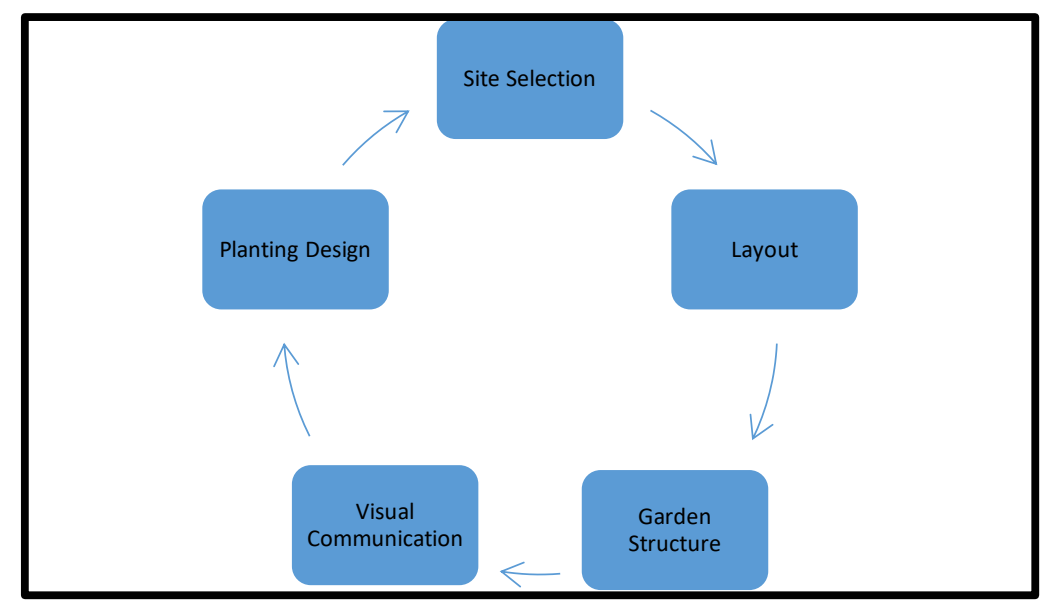

Fig 1. Framework to Design Therapeutic Landscapes

\section{Site Selection}

One of the most important criteria in the scoope of healing garden design is site selection. The aspects to be considered under this title are as follows (Johnson, 1995).

Table 3. Important Criteria for Healing Garden Design

\begin{tabular}{|l|l|}
\hline Criteria & Description \\
\hline Accessibility & $\begin{array}{l}\text { Easy access and transportation criteria must be considered in the site } \\
\text { selection stage of healing gardens, which are designed as gardens and } \\
\text { backyards at locations having the city park characteristics and at health } \\
\text { complexes, including hospitals, nursing homes, etc. in the scope of healing } \\
\text { garden design. }\end{array}$ \\
\hline Topography & $\begin{array}{l}\text { Topography may restrict the size of facility footprint and at the same time, it } \\
\text { may affect order of access to the facility, including the main entrance, } \\
\text { emergency vehicle access and service/personnel access. Site topography } \\
\text { also affects accessibility to building exit, walkways, roadways and parking } \\
\text { lots. Project planning must consider the effect of topography on the functional } \\
\text { and aesthetic aspects of the design. }\end{array}$ \\
\hline
\end{tabular}




\begin{tabular}{|l|l|}
\hline Noise & $\begin{array}{l}\text { According to the conducted researches, natural sounds at healing gardens } \\
\text { have positive effects on humans generally. Examples of these factors are } \\
\text { wind-promoted sounds generated by plant cover, sound of flowing water, } \\
\text { sounds of singing birds. It is crucial that locations away from traffic and city } \\
\text { crowd must be selected in the site selection and design stage of these } \\
\text { gardens. }\end{array}$ \\
\hline Landscape & $\begin{array}{l}\text { Landscape characteristics are beneficial to any site considerably. The first } \\
\text { impression of the facility is made in any urban site by means of landscape. } \\
\text { Landscape is extremely critical in healing gardens and particularly in } \\
\text { therapeutic green areas to achieve healing. Furthermore, visual access to } \\
\text { natural objects may be therapeutic for patients. }\end{array}$ \\
\hline
\end{tabular}

\section{Layout}

- Offers a plain, sharp view of the garden that can be seen from its entry and from a simple, wriggly, circular pathway.

- Provides convenient destinations, including a terrace, tabernacle, booth or summer villa with many seats and a large space to hold social activities and scheduled events.

- Offers a frontier by means of shrubs to obscure fences and walls and to build a safe site, not arousing sense of confinement.

- Offers many selections in terms of seats, pathways, sights, destinations, etc.

- Provides sight of a large landscape for users to feel a sense of belonging to a larger community.

- Provides an area planned for gardening purposes (high beds, tool cabin, large containers, water) to permit the elderly to practice their past skills.

- Offers impressive plants for wheelchair users to touch and smell.

- Caretakers should provide a sharp view of the entire garden from any vantage point (Polat et al. 2017).

Table 4. Garden Structure

\begin{tabular}{|l|l|}
\hline Criteria & Description \\
\hline Entrances & $\begin{array}{l}\text { There must be gateways and entrances incorporated to welcome } \\
\text { visitors. Colorful and impressive plants can be used for this purpose and } \\
\text { art works can be arranged so that the main entrance becomes } \\
\text { prominent and it gives an impression of the site (Shackell et al, 2012). }\end{array}$ \\
\hline $\begin{array}{l}\text { Paths and Spaces } \\
\text { Patterns }\end{array}$ & $\begin{array}{l}\text { Healing gardens consist of direct pathways as crucial components. } \\
\text { Pathways with right angled corners must be eliminated and their slopes } \\
\text { should not be more than 30.5 cm for a length of 6m. Their cross-slopes } \\
\text { should not be more than 30.5cm for a length of 15.24m. When the slope } \\
\text { is higher than 1/20, a support railing must be built to prevent slipping } \\
\text { (Momtaz, 2017). }\end{array}$ \\
\hline Anchor Points and Sitting & $\begin{array}{l}\text { Shaded, comfortable and mobile seats must be provided for people to } \\
\text { rest when they need and they must be placed by a beautiful scene } \\
\text { (Momtaz, 2017). }\end{array}$ \\
\hline Waterflow & $\begin{array}{l}\text { Sound of flowing water in fountains, sunlight reflected on water and sight } \\
\text { of fish in water affect patients positively (Verderber, et al, 2006). } \\
\text { Furthermore, external noise is minimized and sensory interest centers } \\
\text { are generated with the sound of flowing water to attract any age group } \\
\text { with any skill (Momtaz, 2017). }\end{array}$ \\
\hline Illumination & $\begin{array}{l}\text { Sense of well-being is improved, accidential slippings are prevented and } \\
\text { sense of safety is promoted through illumination. There must be } \\
\text { illumination provided at various levels of hallways, slopes and garden } \\
\text { stairs. Moreover, different areas of the garden must be illuminated } \\
\text { appropriately to give a sense of security and to provide an aesthetic sight } \\
\text { to the patients to see through their room windows (Marcus et al, 1995). }\end{array}$ \\
\hline
\end{tabular}




\section{Visual Communication}

Information can be provided effectively by means of a good visual communication and signs to improve visiting experience of users. Graphic components can be used fort his purpose including pictures, plans, colors, typography, signs and placement and a specific attention may be attached the needs of the elderly and users who have cognitive problems, including dementia.

There must be consistency in the communication component style, including texture, material, color, contrast and text. These aspects must be applied in the design of the entire garden and green area and they must not be spoiled. But, excessive information may obscure visual communication and confuse users by promoting wonder and fear that already exists in a stressful place (Neducin et al, 2010).

\section{Planting Design}

Biodiversity and conservation development programs have started to focus on urban areas recently. Biodiversity can be increased by incorporating ecology in urban design in any city, in place of using only the parks, recreational areas and urban forests. Better life quality and human health may be attained by correlating design and ecology and by understanding the way ecological processes run in a city (Bretzel et al, 2012).

One of the components used in landscape design applications is vegetational objects and plant composition formed by these object (Robinson, 1992). In particularly vegetation designs, it is critical that plant structures (leaves, flowers and fruits, etc.) are used aesthetically and functionally, in addition to creating a location with high visual quality (Bekçi et al, 2013). Hence, harsh, solid, dull and lifeless appearances of materials making up the landscape, including stones, wood, concrete, iron, etc. are turned into a more natural and cozy state only by using live, soft and warm-looking materials such as plants. Plants as living materials ensure these influences by means of dynamisms over time however they grow and develop and display their unique features and add the fourth dimension to the landscape only in a specific time period (Acar et al, 2003; Eroğlu and Acar, 2009).

Considering life forms of plants, they can be listed as evergreen plants, deciduous plants, plants which change color in fall, plants which are effective with their flowers, plants which become distinct with the color of their bark during their leafless period or plants which bloom without leafing out, and plants which gain linear dominance.

Conducted researches have shown that nature is a positive stimulant and distractor. Plant use for the benefit of humans and environment is a prerequisite in the landscape designs inspired by nature (Acar, 1997; Kahveci, 2016). Flora, fauna and the entire natural cycles draw attention of people because it is well known that presence of animal species in the garden, including birds, butterflies, etc. are beneficial for patients psychologically due to communication they establish with these animals. Furthermore, people stop for a moment and notice the beauty and balance of nature and wonder and want to discover the species now and then because of color change of leaves during seasonal changes, defoliation, budding, colorful blooming, fruit formation, linear effect following snowing, and arrival of butterflies and birds to the garden and wandering of these animals within the garden and bird singing, etc. in parallel to all of these changes (Kaplan et al, 1998). Most psychiatric patients experience problems in the concepts of time and season. Therefore, seasonal sensations of patients would be improved and positive effects would be created by using plant species with wide leaves that express the seasonal cycle and by preferring plant species having different blooming periods or by using seasonal flowers. According to Sakıcl and Var (2014), gardens composed of natural components have substantial therapeutic effects. Native plants in such types of gardens are used for reviving the past with ecological, visual and functional purposes and for drawing attention and offering spare time activities (Sakıcl and Var, 2014).

\section{Effects of Plant Material Design on Human Health}

Color, sound, scent, touching and form are the design factors which we can sense with our 5 senses and which could affect us psychologically. Inclusion of each factor in a balanced way in the vegetation design and structural design stimulate the sense of tranquility and help alleviate the stress factor. For example, it is well known that richer sensual experiences are achieved by preferring soft-textured, scented plants that make pleasant leaf rustling in wind. 
Designers use plants sensitively for their both functional and aesthetical aspects along with all of their complexities and generate sustainable landscapes. But, sustainable landscape would only be possible by applying vegetation design criteria (harmony and contrast, balance, emphasis, clustering and variety) as harmonized with each other (Bekçi et al, 2013).

Table 5. Plant components ensuring sensational stimulation (Sakıcı, 2009)

\begin{tabular}{|l|l|}
\hline Related with vision & $\begin{array}{l}\text { Unique features of plants } \\
\text { Different branching, flower, fruit, leaf, color, form, } \\
\text { texture, and line characteristics, seasonal changes } \\
\text { Fauna }\end{array}$ \\
\hline Related with hearing & $\begin{array}{l}\text { Acustic experiences } \\
\text { Music, water sound, leaf rustling, sounds of birds, } \\
\text { bugs and wind }\end{array}$ \\
\hline Related with scents & $\begin{array}{l}\text { Plants with pleasant smell } \\
\text { Aromatic leaves, aromatic plants }\end{array}$ \\
\hline Related with touching & $\begin{array}{l}\text { Plants with different textural characteristics } \\
\text { Veins, roughness, hairs, softness }\end{array}$ \\
\hline Related with taste & Edibility characteristics of some plants \\
\hline
\end{tabular}

\section{Selection Criteria for Plants to be used in Therapeutic Landscaping}

In landscape architectural studies, vegetation design attempts to answer user requests by adding function to the location primarily and help restore the equilibrium between nature and people. Feeling, smelling and watching flowers, branches and fruits of plants aesthetically and even hearing the sounds generated by plants in wind and rain improve daily life quality of people in an immesurable level (Karaşah and Var, 2012).

Deciding the plant types in the vegetation design stage is a substantially complex case. Criteria, including characteristics of the environment where the plant is supposed to be planted and ecological, functional and aesthetic features expected in the plant are considered and the plant type is decided. Vegetation designs focus on medicinal and aromatic plants in the researches conducted on healing garden designs (Köse and Güral, 2019). The use of endemic plants in addition to the use of medicinal and aromatic planst would develop the sense of belonging in people and add identity to the site. There are aspects to be taken into consideration in the use of woody and herbaceous plants in healing gardens. For example, it is not actually recommended that coniferous plants are used as they have a disturbing effect but, they may be used as frame species at the sides to define area borders.

It is extremely important to design the hard floor character of the area in planning children's urban playgrounds in addition to planning sites consisting of natural objects and vegetative objects. It must be avoided to use thorny plant species with stinging effects and plants with poisonous fruits or leaves in these areas. In place of these plants, it is recommended to use plant species with edible fruits and plant species with a form that improves imagination of children (cloud formed, ball formed plants, etc.), and soft textured plants and plants with colorful flowers and a pleasant scent.

Plant shades or clutching/climbing plant species may be used to soften harsh appearance of wall surfaces. Unmatched experiences may be offered to users with this approach by supporting flora and fauna formation (birds, butterflies, etc.) Briefly;

- Plants must be selected by studying whether plants have sacred or special meanings in some cultures and certain age groups.

- Medicinal and therapeutic effects of plants must be taken into consideration. It must be attempted to use plants which stimulate any sensation. Plants arouse senses with their various textures, scents and colors in addition to their sounds made by their leaves in the wind. It is critical that seasonal changes are noticed. Users hold on to life with these seasonal changes. 
- The use of thorny and poisonous plants must be avoided in gardens used by particularly children and by persons having some psychological problems.

- There is no need to resort to pesticides by using plants resistant to bugs and diseases.

- High plant beds must be preferred for the users to reach flowers, vegetables or plants easily (Serez 2011). Table 6 shows some plant species that could be used in urban sites based on their therapeutic characteristics.

Table 6. Plant species that can be used in therapeutic landscapes (Güngör et al, 2002; Anşin and Özkan 2006; Mamıkoğlu, 2010)

\begin{tabular}{|c|c|c|c|c|}
\hline & Plant Taxon & Family & Life Form & Design Characteristics \\
\hline \multirow{12}{*}{ 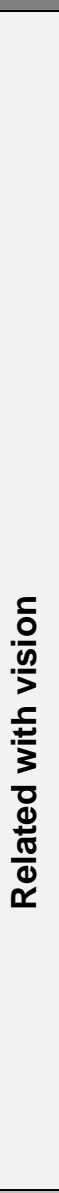 } & Platanus orientalis L. & Platanaceae & $\begin{array}{l}\text { Tree- } \\
\text { Decidious }\end{array}$ & Arouses seasonal change sensation \\
\hline & Albizia julibrissin & Fabaceae & $\begin{array}{l}\text { Tree- } \\
\text { Decidious }\end{array}$ & $\begin{array}{l}\text { Umbrella-formed, it blooms in June- } \\
\text { July and its flowers are light pink } \\
\text { colored with a pleasant scent. }\end{array}$ \\
\hline & Betula pendula & Betulaceae & $\begin{array}{l}\text { Tree- } \\
\text { Decidious }\end{array}$ & $\begin{array}{l}\text { It has a white, aesthetic and } \\
\text { interesting trunk. }\end{array}$ \\
\hline & $\begin{array}{l}\text { Cupressus arizonica } \\
\text { Greene }\end{array}$ & Cupressaceae & $\begin{array}{l}\text { Tree- } \\
\text { Evergreen }\end{array}$ & $\begin{array}{l}\text { Pyramidal top has a large diameter } \\
\text { and it has aesthetic, bluish-green } \\
\text { colored lamellar leaves. }\end{array}$ \\
\hline & $\begin{array}{l}\text { Juniperus horizontalis } \\
\text { Moench }\end{array}$ & Cupressaceae & $\begin{array}{l}\text { Shrub- } \\
\text { Evergreen }\end{array}$ & It is a creeping plant. \\
\hline & $\begin{array}{l}\text { Cotinus coggygria } \\
\text { Scop. }\end{array}$ & Anacardiaceae & $\begin{array}{l}\text { Shrub- } \\
\text { Decidious }\end{array}$ & $\begin{array}{l}\text { Its flowers are yellowish pink colored, } \\
\text { resembling smoke. It has decorative } \\
\text { feature in } 4 \text { seasons. }\end{array}$ \\
\hline & $\begin{array}{l}\text { Abies nordmanniana } \\
\text { subsp. nordmanniana }\end{array}$ & Pinaceae & $\begin{array}{l}\text { Tree- } \\
\text { Evergreen }\end{array}$ & It makes conical and pyramidal tops. \\
\hline & Cedrus libani A.Rich. & Pinaceae & $\begin{array}{l}\text { Tree- } \\
\text { Evergreen }\end{array}$ & $\begin{array}{l}\text { They are monumental trees with } \\
\text { pyramidal form and make oval tops } \\
\text { when they age. }\end{array}$ \\
\hline & Cercis siliquastrum L. & Fabaceae & $\begin{array}{l}\text { Tree- } \\
\text { Decidious }\end{array}$ & $\begin{array}{l}\text { Purplish pink flowers bloom with no } \\
\text { foliage and it is accepted as the } \\
\text { forerunner of spring. }\end{array}$ \\
\hline & Picea orientalis (L.) Link & Pinaceae & $\begin{array}{l}\text { Tree- } \\
\text { Evergreen }\end{array}$ & It is a pyramidal formed plant. \\
\hline & $\begin{array}{l}\text { Lagerstroemia indica } \\
\text { (L.) Pers. }\end{array}$ & Lythraceae & $\begin{array}{l}\text { Tree- } \\
\text { Decidious }\end{array}$ & $\begin{array}{l}\text { It has pink colored, impressive } \\
\text { flowers. }\end{array}$ \\
\hline & $\begin{array}{l}\text { Fagus sylvatica L. } \\
\text { 'Atropurpurea' }\end{array}$ & Fagaceae & $\begin{array}{l}\text { Tree- } \\
\text { Decidious }\end{array}$ & $\begin{array}{l}\text { It is a decorative plant with dark red } \\
\text { colored leaves. }\end{array}$ \\
\hline \multirow{7}{*}{ 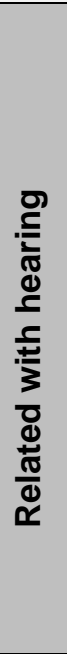 } & Buddleja davidii & Scrophulariaceae & $\begin{array}{l}\text { Shrub- } \\
\text { Decidious }\end{array}$ & $\begin{array}{l}\text { It attracts butterflies and beas and its } \\
\text { flowers are scented. }\end{array}$ \\
\hline & Myrtus comminus L. & Myrtaceae & $\begin{array}{l}\text { Shrub- } \\
\text { Evergreen }\end{array}$ & $\begin{array}{l}\text { White and purple fruits ripen in } \\
\text { September and can be eaten as } \\
\text { snacks. }\end{array}$ \\
\hline & $\begin{array}{ll}\text { Cortaderia selloana } \\
\text { Schult. }\end{array}$ & Gramineae & $\begin{array}{l}\text { Grass- } \\
\text { Evergreen }\end{array}$ & $\begin{array}{l}\text { It has white colored, impressive and } \\
\text { prominent flowers. }\end{array}$ \\
\hline & Pennisetum setaceum & Poaceae & $\begin{array}{l}\text { Perennial- } \\
\text { Grass }\end{array}$ & $\begin{array}{l}\text { It has many purple colored plumose } \\
\text { flower spikes. }\end{array}$ \\
\hline & Festuca glauca & Poaceae & $\begin{array}{l}\text { Perennial- } \\
\text { Grass }\end{array}$ & $\begin{array}{l}\text { Its blue colored leaves give soft } \\
\text { texture sensation. . }\end{array}$ \\
\hline & $\begin{array}{l}\text { Hakonechloa macra } \\
\text { (Makino) Honda }\end{array}$ & Poaceae & $\begin{array}{l}\text { Perennial- } \\
\text { Grass }\end{array}$ & $\begin{array}{l}\text { The leaves intermingle when they are } \\
\text { planted as a ground cover in close } \\
\text { proximity and within decorative urns. }\end{array}$ \\
\hline & $\begin{array}{l}\text { Miscanthus sinensis } \\
\text { Andersson }\end{array}$ & Poaceae & $\begin{array}{l}\text { Perennial- } \\
\text { Grass }\end{array}$ & $\begin{array}{l}\text { The flowers are purplish and situated } \\
\text { above the foliage. }\end{array}$ \\
\hline
\end{tabular}


INONU UNIVERSITY JOURNAL OF CULTURE AND ART / IJCA

İnönü Üniversitesi Kültür ve Sanat Dergisi Volume/Cilt: 6 No/Sayı: 1 (2020) 143-154

\begin{tabular}{|c|c|c|c|c|}
\hline & $\begin{array}{l}\text { Helictotrichon } \\
\text { sempervirens } \quad \text { (Vill.) } \\
\text { Pilg. }\end{array}$ & Poaceae & $\begin{array}{l}\text { Perennial- } \\
\text { Grass }\end{array}$ & $\begin{array}{l}\text { It is a bunchgrass, used as an } \\
\text { ornamental grass in garden design } \\
\text { and landscaping frequently. }\end{array}$ \\
\hline \multirow{11}{*}{ 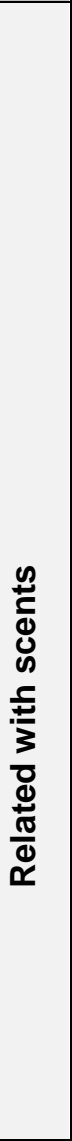 } & $\begin{array}{l}\text { Rosmarinus officinalis } \\
\text { L. }\end{array}$ & Lamiaceae & $\begin{array}{l}\text { Perennial- } \\
\text { Evergreen }\end{array}$ & $\begin{array}{l}\text { It has aromatic smelling leaves and } \\
\text { purple, scented flowers smelling year } \\
\text { round. }\end{array}$ \\
\hline & Salvia officinalis L. & Lamiaceae & $\begin{array}{l}\text { Perennial- } \\
\text { Evergreen }\end{array}$ & $\begin{array}{l}\text { It has violet flowers with interesting, } \\
\text { upright form and has scented leaves. }\end{array}$ \\
\hline & Thymus plogioides L. & Lamiaceae & $\begin{array}{l}\text { Perennial- } \\
\text { Evergreen }\end{array}$ & $\begin{array}{l}\text { The leaves are strongly aromatic, and } \\
\text { it blooms in early summer with lilac } \\
\text { and pink flowers. }\end{array}$ \\
\hline & Allcemilla vulgaris L. & Rosaceae & $\begin{array}{l}\text { Perennial- } \\
\text { Herbaceous }\end{array}$ & $\begin{array}{l}\text { It has medicinal and aromatic } \\
\text { characteristics. }\end{array}$ \\
\hline & Achillea millefolium $\mathrm{L}$. & Asteraceae & $\begin{array}{l}\text { Perennial- } \\
\text { Herbaceous }\end{array}$ & $\begin{array}{l}\text { It is a medicinal aromatic plant with } \\
\text { white flowers. }\end{array}$ \\
\hline & Trifolium pratense $L$. & Fabaceae & $\begin{array}{l}\text { Perennial- } \\
\text { Herbaceous }\end{array}$ & $\begin{array}{l}\text { It is used as an ornamental plant. It } \\
\text { has pink and white impressive flowers } \\
\text { and it is a medicinal aromatic plant. . }\end{array}$ \\
\hline & Primula vulgaris & Primulaceae & $\begin{array}{l}\text { Perennial- } \\
\text { Herbaceous }\end{array}$ & $\begin{array}{l}\text { It has nice smelling orange, yellow, } \\
\text { white, red or purple colored flowers. }\end{array}$ \\
\hline & Melissa officinalis L. & Labiatae & $\begin{array}{l}\text { Perennial- } \\
\text { Herbaceous }\end{array}$ & $\begin{array}{l}\text { Leaves smell like lemon and flowers } \\
\text { are light yellow or whitish. }\end{array}$ \\
\hline & Foeniculum vulgare L. & Umbelliferae & $\begin{array}{l}\text { Perennial- } \\
\text { Herbaceous }\end{array}$ & $\begin{array}{l}\text { It has pleasant smelling, grey-light } \\
\text { green colored, thin, long, thread-like } \\
\text { leaves, turning bronze color in fall. }\end{array}$ \\
\hline & Origanum vulgare L. & Lamiacaea & $\begin{array}{l}\text { Perennial- } \\
\text { Herbaceous }\end{array}$ & $\begin{array}{l}\text { Dark green colored leaves smell like } \\
\text { pepper and it blooms during June and } \\
\text { October and it has white or pink } \\
\text { flowers. }\end{array}$ \\
\hline & $\begin{array}{l}\text { Lavandula angustufolia } \\
\text { L. }\end{array}$ & Lamiaceae & $\begin{array}{l}\text { Shrub- } \\
\text { Evergreen }\end{array}$ & $\begin{array}{l}\text { It has purple flowers and it is a } \\
\text { pleasant-smelling aromatic plant. }\end{array}$ \\
\hline \multirow{6}{*}{ 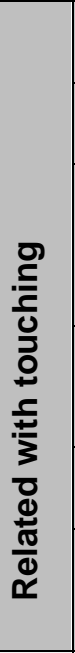 } & $\begin{array}{l}\text { Acer palmatum } \\
\text { 'Atropurpureum' }\end{array}$ & Aceraceae & $\begin{array}{l}\text { Tree- } \\
\text { Decidious }\end{array}$ & Leaves are red, aesthetic. \\
\hline & $\begin{array}{l}\text { Juniperus horizontalis } \\
\text { Moench }\end{array}$ & Cupressaceae & $\begin{array}{l}\text { Shrub- } \\
\text { Evergreen }\end{array}$ & It is a creeping plant. \\
\hline & Hedera helix L. & Araliaceae & $\begin{array}{l}\text { Vine- } \\
\text { Evergreen }\end{array}$ & $\begin{array}{l}\text { It is a climbing plant growing at } \\
\text { appropriate surfaces and it also grows } \\
\text { as a ground-cover at surfaces with no } \\
\text { vertical surface. }\end{array}$ \\
\hline & $\begin{array}{l}\text { Magnolia } \\
\text { soulangeana }\end{array}$ & Magnoliaceae & $\begin{array}{l}\text { Tree- } \\
\text { Decidious }\end{array}$ & $\begin{array}{l}\text { It blooms in spring time without foliage } \\
\text { and it has white, pink and purple } \\
\text { colored impressive flowers. }\end{array}$ \\
\hline & Aesculus $x$ carnea & Sapindaceae & $\begin{array}{l}\text { Tree- } \\
\text { Decidious }\end{array}$ & $\begin{array}{l}\text { It has impressive red flowers and it } \\
\text { bloom in May. }\end{array}$ \\
\hline & Acacia dealbata Link. & Fabaceae & $\begin{array}{l}\text { Tree/Shrub- } \\
\text { Evergreen }\end{array}$ & $\begin{array}{l}\text { Leaves are silver colored and it } \\
\text { blooms in spring, it has yellow, } \\
\text { impressive flowers. }\end{array}$ \\
\hline \multirow{3}{*}{ 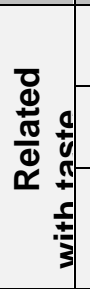 } & Eriobotrya japonica & Rosaceae & $\begin{array}{l}\text { Tree- } \\
\text { Everygreen }\end{array}$ & $\begin{array}{l}\text { The edible orange colored fruits are } \\
\text { aesthetic and functional. . }\end{array}$ \\
\hline & Olea europaea L. & Oleaceae & $\begin{array}{l}\text { Tree- } \\
\text { Evergreen }\end{array}$ & $\begin{array}{l}\text { It has edible fruits and they are green } \\
\text { colored first, turning black later on. }\end{array}$ \\
\hline & $\begin{array}{l}\text { Prunus cerasifera } \\
\text { "Atropurpurea" }\end{array}$ & Rosaceae & $\begin{array}{l}\text { Tree- } \\
\text { Decidious }\end{array}$ & $\begin{array}{l}\text { It blooms in April and it has dark pink } \\
\text { and white colored impressive flowers. } \\
\text { Fruits are reddish and edible. }\end{array}$ \\
\hline
\end{tabular}




\begin{tabular}{|l|l|l|l|l|}
\hline & Hibiscus syriacus L. & Malvaceae & $\begin{array}{l}\text { Shrub- } \\
\text { Decidious }\end{array}$ & $\begin{array}{l}\text { The flowers are generally pink, but } \\
\text { they can also be dark pink (almost } \\
\text { purple), light pink or white. }\end{array}$ \\
\cline { 2 - 4 } & Ficus carica L. & Moraceae & $\begin{array}{l}\text { Tree- } \\
\text { Decidious }\end{array}$ & $\begin{array}{l}\text { The fruit is edible. It is a rough textured } \\
\text { tree in summer and a thin textured tree } \\
\text { in winter. }\end{array}$ \\
\hline Cerasus avium & Rosaceae & $\begin{array}{l}\text { Tree- } \\
\text { Decidious }\end{array}$ & $\begin{array}{l}\text { It is a red-fruited plant with white } \\
\text { flowers in spring. }\end{array}$ \\
\hline
\end{tabular}

\section{Conclusion}

Nature, which was first used as a means of transgression and spiritual maturation (nirvana) in Far East countries and India especially in religious terminology (Hinduism and Buddhism), which dates back to 563 BC$483 \mathrm{BC}$, started to be used as a psychological improvement approach. It has been used effectively especially in awareness therapy and meditation practices (Sarıçam et al, 2015).

People have been living intertwined with nature until their modern age. In the modern era of industrialization, crowded concrete-covered urban environments forced people to break with their nature, and this caused considerable damage to the inner world. For this reason, the most effective way to solve the problems that people experience in their inner world is recalling nature; it is part of its re-learning and integration with nature. As it is known, planting and landscape design; It stimulates the senses of people in an interesting and gentle way by recommending the use of elements such as size, form, color and texture (Serez 2011). As we know; vegetation and landscape design suggest using components together, including measure, form, color and texture that arouse senses in an interesting and delicate way (Serez 2011). With landscape design projects, people can come into contact with nature, and the elderly and people with psychological discomfort can experience seasonal transitions. In this direction, it turns out that green areas, which have a wide range of healing properties, are of high importance for public health and future. Consequently, it is a scientifically accepted reality to consider the decisions "an integrated approach" in planning studies for determining the therapeutic and curative (physical, spiritual) roles of green systems for urban residents in urban areas. For this reason, it is vital to give importance to therapeutic landscape practices in intensive urban life and to establish infrastructure for landscape projects in this context.

As a result, reaching decisions with a holistic approach is a scientifically accepted reality in the planning studies conducted to designate the therapeutic and healing roles of green systems for the persons living in urban areas in cities.

In this context, we can list our suggestions as follows;

- Informing public institutions and organizations and the private sector about the benefits of the therapeutic landscape

- Providing budget allocations to therapeutic landscape studies in public institutions and organizations

- Establishment of non-governmental organizations and associations on the subject

- Enabling the concept of therapeutic gardens, which have become widespread in developed countries, to become widespread all over the world,

- Enabling experts from different professional disciplines (landscape architects, psychologists, engineers etc.) to work together and produce projects.

\section{REFERENCES}

Acar, C., 1997. A study on the use of some ground-covering native plants grown in Trabzon and its environs in landscape architecture, doctorate thesis, Black Sea Technical University, Institute of Science, Trabzon

Acar C., Demirbaş E., Dinçer P. and Acar H., 2003. An Assessment of Semantic Differentiation Technique in Plant Composition Examples, Journal of Süleyman Demirel University, Faculty of Forestry, Serial: A, Issue: 1, ISSN: 1302-7085, Sayfa:15-28. 
Anşin, R. and Özkan, Z.C., 2006. Tohumlu Bitkiler (Spermatophyta), Odunsu Taksonlar, Karadeniz Teknik Üniversitesi Orman Fakültesi No:167-19, Karadeniz Teknik Üniversitesi Basımevi, Trabzon.

Ayaşlıgil, Y. (2011). Şifalı Bitkiler ve Şifa Bahçeleri Tasarımı Üzerine Araştırmalar. Yüksek Lisans Tezi (yayımlanmamış), İstanbul Üniversitesi Fen Bilimleri Enstitüsü. İstanbul, $159 \mathrm{~s}$.

Bekçi B., Var M., and Taşkan G, 2013. The Use of Native Species in Urban Vacant Sites in the Context of Vegetation Design Criteria: Bartın, Turkey, Artvin Coruh University Journal of Forestry Faculty, ISSN: 21461880, e-ISSN: 2146-698X, Vol: 14, Issue: 1, Pages: 113-125.

Bretzel, F., Malorgiob F., Paoletti L., Pezzarossaa B., 2012. Response of sowed, flowering herbaceous communities suitable for anthropic Mediterranean areas under different mowing regimes, Landscape and Urban Planning, G Model, LAND-2217; No. of Pages 9.

Erickson, M.S., 2012. Restorative Garden Design; Enhancing Wellness through Healing Spaces. Art and Design Discourse. Vol. 2.

Eroğlu, E. and Acar, C. 2009. Trabzon ve Yakın Çevresi Bazı Yayla Alanlarındaki Alpin Bitkiler ve Peyzaj Mimarlıgı Çalısmalarında Kullanım Potansiyelleri, Düzce Üniversitesi Ormancılık Dergisi, Cilt 5 , Sayı 1, Sayfalar $42-59$.

Göker, P., Tuna, A. 2017. "Analysis of Persian Historical Gardens in the Scope of Healing Design", There Pillars of Landscape Architecture: Design, Planning and Management. New Visions, 8-10 June, St. Petersburg, Russia.

Göker, P., 2017. "A New Approches to Human and Nature; Eco Cities". International Multidisipliner Congress. 25-26 November, Antalya.

Güngör İ., Atatoprak A., Özer F., Akdağ N. ve Kandemir N. I., 2002. Plant World, Details of Plant Introduction and Principles of Arboriculture, Laser Offset Publication Facilities Industry and Trade Ltd. Co., ISBN 97597874-0-7, Ankara.

Johnson, C. W., 1995. Planning and designing for the multiple use role of habitats in urban/suburban landscapes in the Great Basin. Landurbplan 32, 219-225.

Kahveci, H., 2016. An Assessment of Plant Cover of the Eastern Black Sea Coastal Region in terms of Landscape Architecture, Black Sea Technical University, Institute of Science, Doctorate Thesis, Trabzon.

Karaşah, B. ve Var, M. (2012). Trabzon ve Bazı İlçelerinde Kent Dokusundaki Bitkilendirme Tasarımlarının Ölçü-Form Açısından İrdelenmesi, Bartın Orman Fakültesi Dergisi, Cilt: 14, Özel Sayı, 1-11 ISSN: 1302-0943 EISSN: 1308-5875.

Kaplan, R., S. Kaplan and R.L. Ryan, 1998. With People in Mind: Design and Management of Everyday Nature. Island Press, Washington, D. C.

Kellert, S.R. 1997. Kinship to Mastery: Biophilia in Human Evolution and Development. Island Press, Washington, DC.

Kellert, S.R., 2002. Experiencing nature. In: Kahn, P., Kellert, S. (Eds.), Children and Nature. MIT Press, Cambridge.

Kellert, S. R., Heerwagen, J. H., Mador, M. L. 2008. Biophilic design: the theory, science and practice of bringing buildings to life, John Wiley\&Sons, Inc. 
Kendle A. D., Rohde C. R. E. 1995. Relative importance of uncontrolled and ordered nature for people in urban areas. In: J. De Waal (Ed), Ecological Aspect of Green Areas in Urban Environments, Proceedings of the 1995 IFPRA World Conference 3-8 September, 55-58, Bruge, Belgium.

Khansari, M., Moghtader, MR \& Yavari, M., 1998. Persian Garden: Echoes of Paradise, Mage Publishers, Washington DC.

Köse S. and Güral, S. M., 2019. Medicinal and Aromatic Plants and Their Use in Landscapes, LANDSCAPE - Journal of Education, Science, Culture and Arts, 1, 41-54.

Mamıkoğlu, N. G., 2010. Trees and Bushes of Turkey, Doğuş Group Communication Publication and Trade Ltd. Co., NTV Publications, ISBN: 978-605-5813-49-9, Istanbul.

Marcus, C. C. and Barnes, M.,1995. Gardens in healthcare facilities: Uses, therapeutic benefits, and design recommendations, The Center for Health Design, Inc

Momtaz, R. I. 2017. Healing Gardens - A Review of Design Guidelines. International Journal of Current Engineering and Technology. E-ISSN 2277 - 4106, P-ISSN 2347 - 5161

Neducin, D., Krklijes, M. Kurtovic-Folic, N. 2010. Hospital Outdoor Space-Therapeutic Benefits and Design Consideration. Architecture and Civil Engineering Vol. 8, No 3, 2010, pp. 293 - 305

Orman, P., 2017. Understanding the Biophilia Hypothesis through a Comparative Analysis of Residential Typologies in Phoenix, São Paulo, and Tokyo. Master Thesis. Arizona State University.

Robinson, N., 1992. The Planting Design Handbook, Gower Publishing Company Limited Gower House Craft Road Aldershot Hampshire Gu11 3HR, England, 271p.

Sacamano, D., 2009. An Introduction to Healing Gardens and Creating Low-cost Wellness Feathers. Oregon Office of Rural Health. Oregon Health and Science University. Washington

Sakıcı Ç., Var M., 2014. Criteria in organization of gardens of psychiatric hospitals (outdoor therapy units), Journal of Kastamonu University, Faculty of Forestry, 14(1), 101- 112

Sakıcl, Ç., 2009. Landscape design of outdoor therapeutic units of psychiatric hospitals: Example of Ataköy (Trabzon) Psychiatric Hospital (unpublished doctorate thesis), Black Sea Technical University, Institute of Science, Department of Landscape Architecture, Trabzon

Sarıçam H., Şahin S. H., Soyuçok E., 2015. The Examination of The Relationship Between Nature Relatedness, Depression, Anxiety And Stress, International Journal Of Psychiatry And Psychological Researche S, Jel Kodu: I0-I11-I12-I30 ID:36 K:49, ISSN 2148-8215 ONLINE ISSN:2149-2506.

Serez, A., 2011. Health Gardens in the Historical Process, Istanbul Technical University, Institute of Science, Master's Thesis, pg: 12-57, Ankara.

Shackell, A. and Walter, R., 2012. Practice Guide Green spaces design for health and well being, Forestry Commission: Edinburgh.

Vappa, A.G., 2002. Healing Gardens: Creating Places for Restoration, Meditation, and Sanctuary. Master 's The-sis. Virginia Polytechnic Institute and State University, College of Architecture and Urban Studies

Verderber, Stephen and Refuerzo, Ben J.,2006. Innovations in Hospice Architecture, Taylor \&Francis.

Wilson, E.O., 1984. Biophilia: The Human Bond with Other Species. Harvard University Press, Cambridge, MA 